\title{
Influence of Static and Impact Load on Pavement Performance
}

\author{
Audrius Vaitkus, Judita Gražulyte, Rita Kleizienè \\ Road Research Institute, Vilnius Gediminas Technical University, Linkmenu str. 28, LT-08217 Vilnius, Lithuania
}

\begin{abstract}
The most researches are done for evaluation of dynamic load of vehicles on pavement response. However, pavements of airports, container terminals, logistic terminals, areas of storage, industrial areas, parking lots, areas operated by falling materials or special machinery and etc. are affected by long term static or impact load. Due to this kind of loading specificity, pavement performance is different comparing to pavement performance operated by repeating dynamic traffic loads. Practice shows, that permanent (plastic) deformations and thermal cracks often appear in such pavements. Consequently, the loading specification of areas affected by static and impact load, development of permanent deformations and thermal cracking and analysis of practice and normative requirements for pavements affected by static and impact load were considered in this research. The research has resulted in serviceable solutions for pavement structures resistant to static and impact loading according to the type of pavement (flexible, rigid, semi-rigid (flexible)) and the scope of application.
\end{abstract}

Keywords: static load; impact (drop weight) load; pavement failure; pavement structure.

\section{Introduction}

A pavement is a multi-layer structure, which performance depends on each layer characteristics. As it is well known, stiffness modulus is the basic characteristic for bituminous materials. Meanwhile, resilient modulus and/or California Bearing ratio characterizes unbound granular materials. Whereas flexural and compression strength is the most important characteristic for cement or cement treated materials. The selection of thickness of each layer depends on heavy traffic volume, design period, axle combination, axle load, wheel load, contact area and etc. [1-4]. All of these factors are summed up in pavement design methods.

Approximately $60 \%$ of the European countries use analytical design methods, which are based on linear elastic theory. This concept is used to calculate permissible values of stress or strain at critical locations in the pavement structure [1]. However, it requires lots of computation of time and experiences. So, in most countries there are prepared some catalogues for pavement structure selection according to a number of equivalent single axle load (ESAL) through design period. There are considered into specific climatic conditions (level of groundwater, level of frozen, ambient temperature) of country, too.

The distresses of pavement is accelerated by influence of climatic conditions (temperature, moisture, freeze-thaw cycling) [5-6]. Temperature is emphasized as most critical environmental factor. Temperature variations affect the viscouselastic-plastic characteristic of asphalt pavement. The change of behavior depends on temperature (low - elastic (stiff) material, medium - viscous-elastic material, high - plastic material) [7-9]. In the rigid pavements, daily temperature variations lead curling of the slab: the slab bend up (expansion of the pavement surface) when the top of the slab is much higher temperature than the bottom of the slab (daytime) and the slab bend down (contraction of the pavement surface) when the temperature at the top of the slab is much lower than the bottom (nighttime). Also, the temperature variations give thermal stresses in the slab [10-12].

Hence, distresses of the pavement are caused due the action of heavy traffic loads and climatic conditions (especially temperature variations). There are noted that asphalt pavements distress are dominated by permanent deformation (rutting in the subgrade, rutting in base layers and/or rutting in bituminous layers), fatigue cracking, thermal cracking, structural cracking, surface cracking, alligator cracking, longitudinal cracking, transverse cracking, reflective cracking, raveling, wear by studded tires, loss of skid resistance [1], [13], [14]. Whereas concrete pavements distress are dominated by curling of slabs, corner breaks, longitudinal cracking, thermal cracking, D-cracking, fatigue cracking, spalling, transverse slab

Corresponding author: Audrius Vaitkus. E-mail address: audrius.vaitkus@vgtu.lt

http://dx.doi.org/10.3846/enviro.2014.173

(C) 2014 The Authors. Published by VGTU Press. This is an open-access article distributed under the terms of the Creative Commons Attribution License, which permits unrestricted use, distribution, and reproduction in any medium, provided the original author and source are credited. 
cracking, reflective cracking, faulting, blowups [14-17]. Pavements with such kind of distresses don't satisfy the requirements of exploitation and need structural rehabilitation or reconstruction. That is why; the concept of perpetual (long-life) pavements has been developed. It means that a pavement is a maintenance-free - no structural deterioration of the pavement whatever the traffic load. This kind of pavement life is about 50 years and need only periodic surface renewal in response to distresses confined to the top of the pavement [18-20].

Pavement performance and distresses that are discussed above is typical for roads, which are operated by repeating dynamic traffic loads. However, there are some pavements, which are affected by different type of load: static or impact loading. There is known that static load is load, which direction of effect, value and coordinates of added point is constant and source of loading do not take significant acceleration during loading time. Whereas impact load is load (weight), which drops from certain high and suddenly (within $10^{-3} \div 10^{-6} \mathrm{~s}$ ) covers the pavement. At the finish time of impact, the speed of dropping load is zero. This kind of loading is induced by falling materials or special machinery.

Static and/or impact loading emerge at parking aprons of aircraft, ports and containers terminals, logistics terminals, industrial areas, parking lots, waste recycling areas and etc. In these areas the values of loads are several time higher comparing with common traffic loads. Time of loading is longer, too. Moreover, loads of these areas are concentrated and affect pavement within small contact area. Consequently, it leads high pressure into pavement. Hence, these kinds of pavements perform in different way comparing to roads pavements and need to be properly analyzed.

Practice has shown that pavements which are affected by static and impact loading need structural rehabilitation or reconstruction much earlier than projected their design life. The main reason of it is distresses or failures of the upper part of pavement (generally wearing layer). The most significant distresses are permanent (plastic) deformations [21] and thermal cracks (if pavement has been constructed in cold regions) [23], [24]. Often, the form of permanent deformations reflects the shape of contact area of loading source. It obviously appears in flexible or semi-rigid pavements with asphalt layers.

\section{Particularity of areas affected by static and impact load}

The performance of pavement affecting by static and impact load strongly depends on contact pressure. In calculations it is assumed that the average tire contact pressure is proportional to tire pressure and remains uniform by changing load. Hence, the contact area varies only by changing load. Then the load is increasing (tire pressure is uniform), the contact area is increasing and then the load is decreasing, the contact area is decreasing, too [2].

For current range of load and tire inflation pressures, the real tire-pavement contact area is similar to a rectangle or an ellipse [25]. There is an assumption, that the ellipse's smaller axle or rectangle width is usually considered as $60 \%$ of the ellipse's larger axle or rectangle length [26]. In calculations tire-pavement contact area is accepted as a circle, which area is equal to ellipse's (rectangle) area.

In areas affected by static and impact load, the contact pressure closely depends on characteristics of loading source. There dominates such load sources: aircrafts, containers, handling equipment (rubber tire gantry cranes (RTGs), straddle carriers, reach stackers, front lift trucks, side loader lift trucks and etc.), storage goods, trucks, cars and/or dropping objects (Fig. 1). Due variety of load sources and their characteristics, contact pressure is given in Table 1.

Table 1. Contact pressure considering to characteristics of load source ${ }^{\text {a) }}[2],[27-30]$

\begin{tabular}{|c|c|c|}
\hline Object (load source) & Contact area, $\mathrm{mm}^{2}$ & Contact pressure, $\mathrm{MPa}$ \\
\hline Aircraft & b) & $0.3-1.7^{\mathrm{c})}$ \\
\hline Handling equipment of ports & b) & $0.7-1.7$ \\
\hline Container & 26250 & $2.59-12.5^{\mathrm{d})}$ \\
\hline Heavy vehicle & b) & $0.6-1.0$ \\
\hline Trailer dolly (steel wheels) & 8800 & $35-40$ \\
\hline Trailer pivot plate & 33750 & 2.0 \\
\hline Handling equipment of industrial areas & b) & $0.5-1.0$ \\
\hline EuroPallet & 116000 & $0.03-0.44^{\mathrm{e})}$ \\
\hline Car & b) & $0.20-0.25$ \\
\hline
\end{tabular}

\footnotetext{
a) Sources of impact load haven 't been included in to table due to their variety.

b) The leg of load source is wheel. The contact area of tire-pavement depend on characteristics of tire.

c) Contact pressure depends on type of aircraft.

d) Then only one container is on the pavement the contact pressure is $2.59 \mathrm{MPa}$, then eight containers $-12.5 \mathrm{MPa}$.

e) Then only one EuroPallet with goods is on the pavement the contact pressure is from $0.03 \mathrm{MPa}$ depending on the weight of goods, then four EuroPallet with goods - by $0.44 \mathrm{MPa}$ depending on the weight of goods.
} 


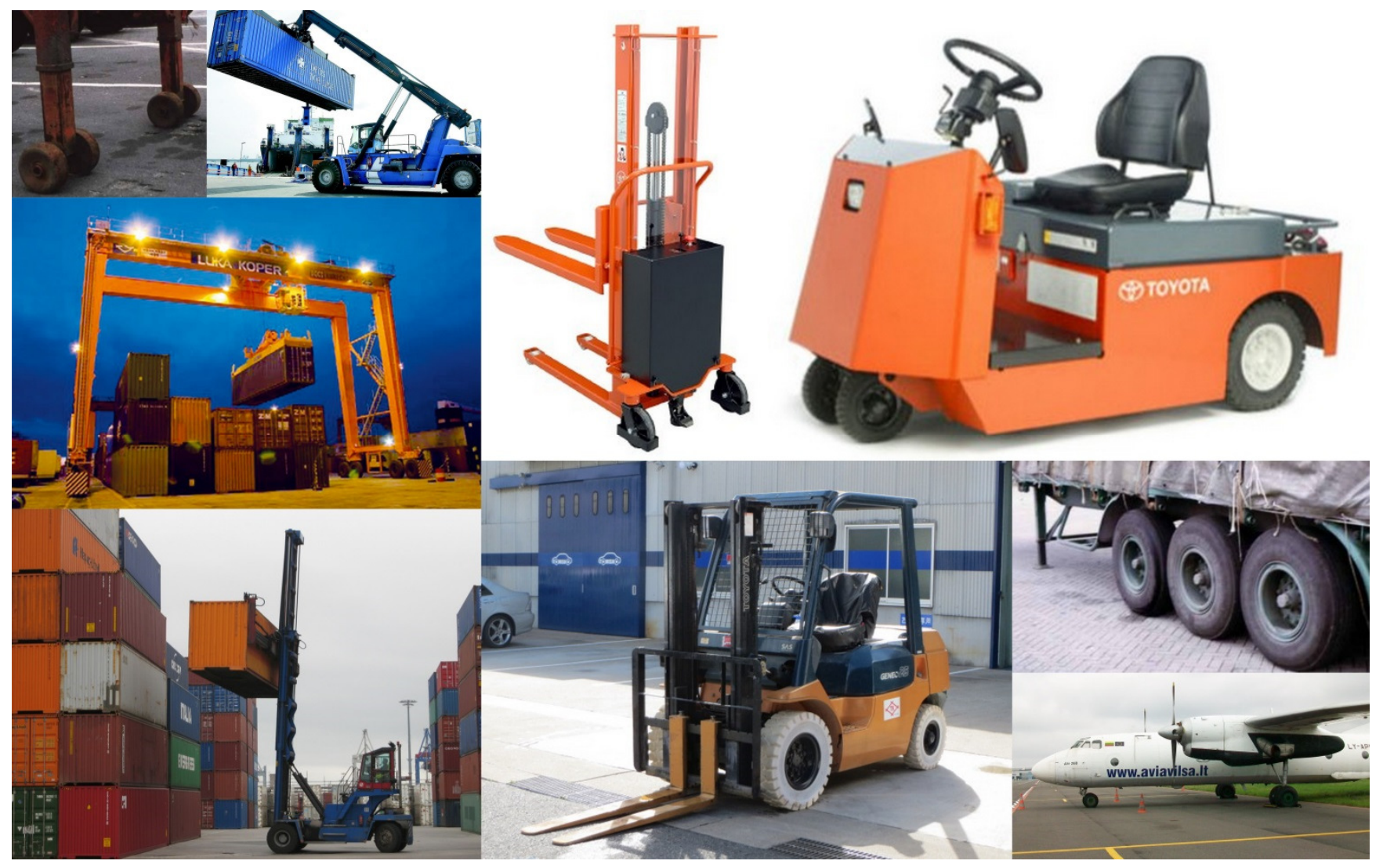

Fig. 1. Examples of loading sources

The aircraft gear type and geometry needs to be estimated in analysis of pavement performance at parking aprons of aircrafts. Whereas analyzing the pavement performance at ports and container terminals, there should be noticed into different loading, i.e. static loading (containers) and dynamic loading (handling equipment's movements, cornering, accelerating and braking).

According to DIN/ISO standards, fully loaded containers must be stackable at least six high. Practice has shown that fully loaded containers are usually stacked up to six high and empty containers - eight high. However, there can be used modern containers, which can be stacked up to eight or nine high even fully loaded (in some cases containers can be stacked up to twelve high) [28], [30], [31].

EuroPallets are the main type of foundation for goods storing in industrial areas. For storage they can be stacked up to four high and for transportation - up to two high.

There has been assessed that the load on pavement depends on containers and EuroPallers stacking arrangement and wheel configuration. The closer wheels or legs of load are the greater loads on pavement. However, the contact pressure is constant at contact area and varies only by stacking high (if contact area is uniform) [28], [30].

In areas affected by impact load, pavement response to loading depends not only on the load value, contact area, but also on the dropping high. The negative effect of loading increases as the dropping high increases.

\section{Distress of pavement structures affected by static and impact load}

In pavement structures affected by static and impact load the main distresses are permanent deformations (surface depression in the contact area) (Fig. 2) [32], [33] and thermal cracks (Fig. 3) [34], [41]. As mentioned before, due viscouselastic-plastic properties of asphalt and ambient temperature variation these distresses commonly appear in asphalt pavements [35], [36]

Permanent deformation of asphalt layer is caused by [4], [34], [37]:

- Densification (volume change);

- Shear flow (no volume change);

- Mechanical deformation (structural failure).

Due loading asphalt layers consolidate. This consolidation results in surface depression in the contact area without an accompanying hump on either side of the depression. This phenomenon is inescapable and can be limited by content of air voids in asphalt mixture. Asphalt pavements are typically constructed at approximately 5-8\% in-place air voids. Due loading content of air voids decreases to approximately $4 \%$. Air voids content less than $2-3 \%$ leads asphalt's susceptible to shear flow [29], [38]. So, asphalt layers must be not overdensified. 
Longitudinal or lateral distortion of asphalt mixture is caused by instability of asphalt layers, i.e. by large shear stresses dominating in the upper part of asphalt layers. This distress can be recognized by humps on either side of the depression. Ratio of this kind of deformation depends on moving speed and temperature. The same load leads higher deformation at lower speed and higher temperature. Permanent deformation caused by shear flow is difficulty predictable phenomenon.

Mechanical deformation is associated with permanent deformation in any of the pavement layers or in the subgrade. It develops due consolidation, densification and/or lateral movement of the unbound materials. The deformations evolving in the lower part of the pavement structure reflects in the upper part of the pavement. If asphalt is too stiff (high elastic modulus), mechanical deformations is usually accompanied by a longitudinal cracking pattern at the pavement's surface.

Development of asphalt's permanent deformation is influenced by characteristics of binder and aggregate, content of air void and binder, ambient temperature, load magnitude, loading time and etc. [37], [38].

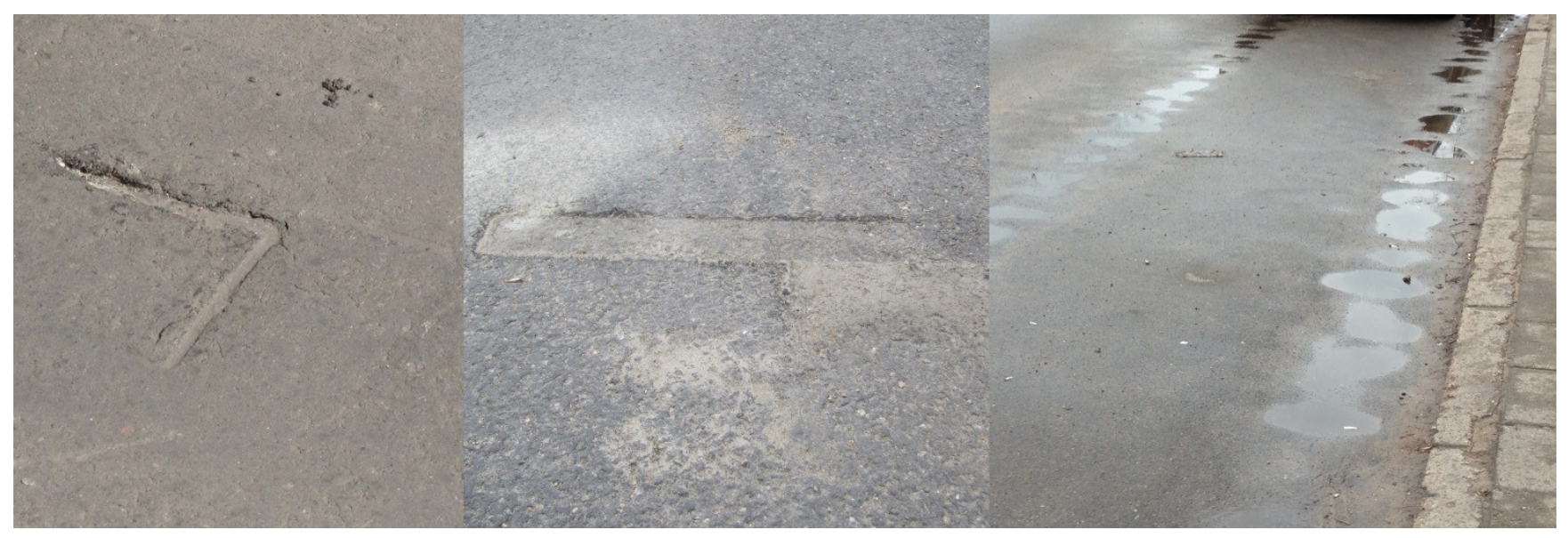

Fig. 2. Permanent deformations of pavement effected by static and impact loading

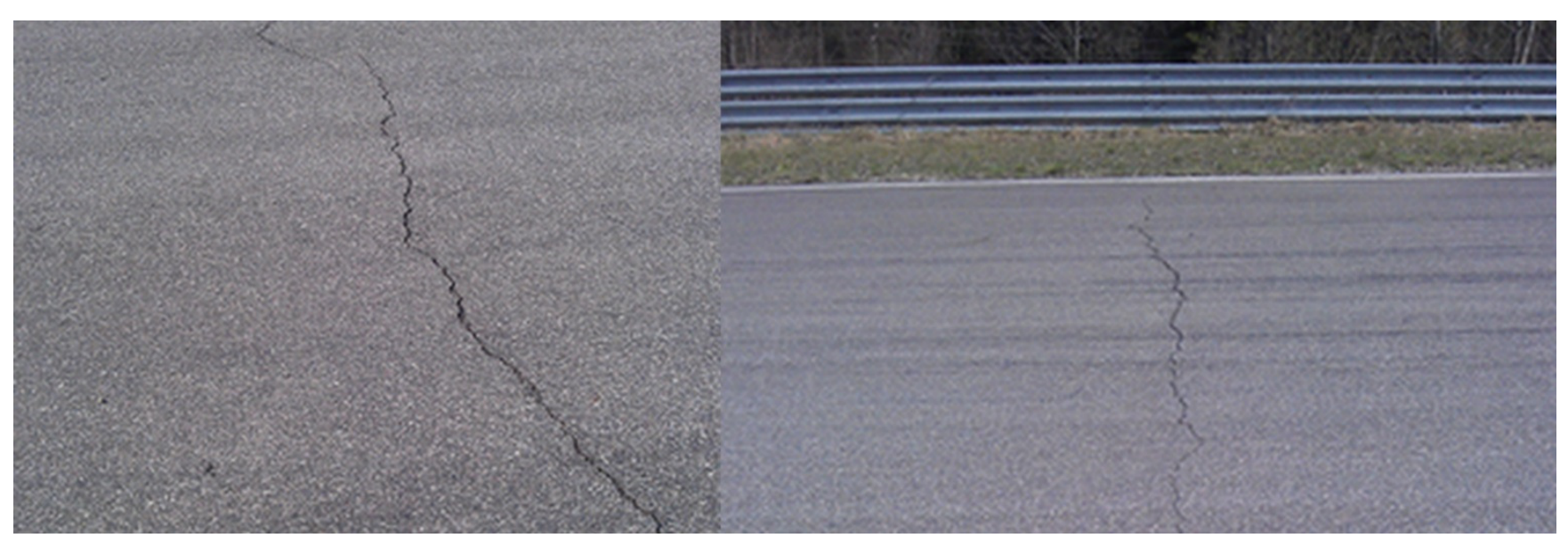

Fig. 3. Thermal cracking of asphalt pavements

During hot summer weather the temperature in the surface course of the asphalt pavement structure can exceed $50{ }^{\circ} \mathrm{C}$. In Lithuania it changes during the year from $-21.77^{\circ} \mathrm{C}$ to $+52.75^{\circ} \mathrm{C}$, the difference is more than $70^{\circ} \mathrm{C}$ [39]. The reason of it is that around $55 \%$ and $85 \%$ of solar radiation is absorbed by the surface of asphalt pavement respectively in winter and summer time [40]. The highest temperature in the surface course is about 12-16 hour in summer time. Researchers has found that majority of surface depression (permanent deformation of asphalt layers) occurs on a few days of the year, when the temperature in the surface course exceeds $45^{\circ} \mathrm{C}$ [41]. Due such high temperature the asphalt mixture behaves as plastic material. This problem can be solved by using a stiffer asphalt binder. However, stiffer asphalt binders are more prone to cracking during winter in cold regions [34].

Thermal cracking is primarily associated with cold temperatures (below $10^{\circ} \mathrm{C}$ ) at the surface of asphalt layer. Due to low temperature the binder film to get thinner around aggregates. When the temperature drops below the point where asphalt binder becomes brittle, thermal cracking is initiated in the surface of asphalt pavement and immediately grows down. This type of distress can be controlled through selection of binder for expected minimum temperature of the pavement [40], [42]. 


\section{Solutions for pavement structure performance}

On purpose to establish the best solutions for pavement structure affected by static and impact load, there were researched successful practice in using this kind of pavements and normative requirements for parking aprons of aircraft, ports and containers terminals, logistics terminals, industrial areas, parking lots and etc. The type of pavement (flexible, rigid, semirigid (flexible)), layers thickness and characteristics were analyzed by the scope of application. This methodology of the research led to establish the most typical pavement structures resistant to static and impact loading. All analyzed information has been summarized in Appendix A. It represents presumable solutions for pavement structures resistant to static and impact loading.

According to the scope of application, the analysis of foreign countries practice has resulted in such preferable solutions to pavement structures:

- Concrete pavements or pavements with concrete paving blocks are recommended for parking aprons of aircraft. Asphalt pavements are not recommended for these applications. However, it can be used as alternative choice.

- Pavements with paving blocks are recommended for ports and containers terminals. Concrete pavements are strongly recommended for containers stacking areas. While asphalt pavements can be used as alternative choice for areas affected by moving handling equipment.

- Concrete pavements, pavements with concrete paving blocks or porous asphalt with cement grout are recommended for logistics terminals. Asphalt pavements can be used as alternative.

- Concrete pavements and pavements with concrete paving blocks or porous asphalt with cement grout are recommended for industrial areas. Concrete pavements are recommended for goods stacking areas. While asphalt pavements can be used as alternative choice for areas affected by moving handling equipment.

- Asphalt pavements are mostly recommended for parking lots.

\section{Conclusions}

Due to changes of viscous-elastic-plastic behavior and variations of ambient temperature, asphalt pavements are considered as the most susceptible pavements to static and impact loading.

The use of standardized pavement structures in areas affected by static and impact loads is unreasonable due to significant range of varying contact pressure (contact pressure varies from $0.2 \mathrm{MPa}$ to $12.5 \mathrm{MPa}$ depending on load, axle configuration, gear type and geometry, number of wheel, contact area and etc.).

In the areas affected by static and impact load (such as parking aprons of aircraft, ports and containers terminals, logistics terminals, industrial areas, parking lots, waste recycling areas and etc.) the most significant distresses are permanent deformations and thermal cracking (if pavement has been constructed in cold regions).

The pavement resistance to static and impact loading should be ensured by sufficient bearing capacity of pavement structure and stiffness of payment layers affected by high contact pressure. The solution for this purpose can be achieved by constructing $2.5-10 \mathrm{~cm}$ thick stiff asphalt surface course, $8-20 \mathrm{~cm}$ thick course of concrete paving blocks, $10-60 \mathrm{~cm}$ thick concrete course or 3-7 cm thick course of porous asphalt with cement grout. The thickness of wearing course depends on contact pressure and should be calculated dependent on loading conditions.

\section{Acknowledgements}

This paper summarizes the first part of the work being developed by the project "The model of pavement structure resistant to static and impact loading adopted to changing climate conditions". Number of project is VP1-3.1-ŠMM-10-V-02-022. The project is financed by European social fund.

\section{References}

[1] COST 333. 1999. Development of New Bituminous Pavement Design Method: Final Report of the Action. European Commission, Directorate General Transport, Luxembourg. 375 p. ISBN 92-828-6796-X.

[2] COST 334. 2001. Effects of Wide Single Tyres and Dual Tyres. Final Report of the Action. European Commission, Directorate General Transport, Belgium. $170 \mathrm{p}$.

[3] AASHTO. 1993. Guide for Design of Pavement Structures. Washington: AASHTO. 324 p.

[4] Huang, Y. H. 2004. Pavement Analysis and Design.United States of America: Prentice Hall. 792 p. ISBN 0-13-142473-4.

[5] Bhattacharjee, S.; Mallick, B. R. 2012. Effect of Temperature on Fatigue Performance of Hot Mix Asphalt Tested Under Model Mobile Load Simulator, International Journal of Pavement Engineering 13(2): 166-180. http://dx.doi.org/10.1080/10298436.2011.653565

[6] Leonovič, I.; Melnikova, I. 2012. Influence of Temperature on the Formation of Damages in Asphalt Concrete Pavements under Climatic Conditions of the Republic of Belarus, The Baltic Journal of Road and Bridge Engineering 7(1): 42-47. http://dx.doi.org/10.3846/bjrbe.2012.06

[7] Kim,Y. R.; Lee,Y. C. 1995. Interrelationships among stiffnesses of asphalt-aggregate mixtures, Journal of the Association of Asphalt Paving Technologists 64: 575-609

[8] Park, H. M.; Kim, Y. R.; Park, S. 2002. Temperature correction of multiload-level falling-weight deflectometer deflections, Transportation Research Record 1806: 3-8. http://dx.doi.org/10.3141/1806-01 
[9] Shao, L.; Park, S. W.; Kim, Y. R. 1997. Simplified procedure for prediction of asphalt pavement subsurface temperatures based on heat transfer theories, Transportation Research Record 1568: 114-123. http://dx.doi.org/10.3141/1568-14

[10] Rufino, D.; Roesler, J. 2005. Effects of Temperature Curling on Airfield Rigid Pavement Responses, Road Materials and Pavement Design 6(3): $311-$ 337. http://dx.doi.org/10.1080/14680629.2005.9690010

[11] Qin, Y.; Hiller, J. E. 2011. Modeling temperature distribution in rigid pavement slabs: Impact of air temperature, Construction and Building Materials 25(9). http://dx.doi.org/10.1016/j.conbuildmat.2011.04.015

[12] Westergaard, H. M. 1926. Analysis of stresses in concrete pavement due to variations of temperature, in Proc. of Highway Research Board 6: 201215.

[13] Sanchez-Silva, M.; Arroyo, O.; Junca, M.; Caro, S.; Caicedo, B. 2005. Reliability based design optimization of asphalt pavements, International Journal of Pavement Engineering 6(4): 281-294. http://dx.doi.org/10.1080/10298430500445506

[14] Lenz, R. W. 2011. Pavement Design Guide. Texas. 428 p.

[15] Griffiths, G.; Thom, N. 2007. Concrete Pavement Design Guidance Notes. London and New York: Taylor and Francis Group. 168 p. ISBN 978-0203-96206-0

[16] T.I.C. 2002. Concrete Pavement Surface Evalutaion and Rating (PASER) Manual. Wisconsin Transportation Information Center (T.I.C.), Madison, Wisconsin. $28 \mathrm{p}$.

[17] FAA. 2004. Concrete Airfield Pavement Surface Evaluation and Rating (PASER) Manual. Federal Aviation Administration (FAA), Washington, USA. $20 \mathrm{p}$.

[18] Timm, D.; Newcmb, D. 2006. Perpetual pavement design for flexible pavements in the US, International Journal of Pavement Engineering 7(2): 111119. http://dx.doi.org/10.1080/10298430600619182

[19] Chenevière, P.; Ramdas, V. 2006. Cost benefit analysis aspects related to long-life pavements, International Journal of Pavement Engineering 7(2): 145-152. http://dx.doi.org/10.1080/10298430600627037

[20] Ferne, B. 2006. Long-life pavements-a European study by ELLPAG, International Journal of Pavement Engineering 7(2): 91-100. http://dx.doi.org/10.1080/10298430600619059

[21] Wasage, T.; Statsna, J.; Zanzotto, L. 2010. Repeated Loading and Unloading Tests of Asphalt Binders and Mixes, Road Materials and Pavement Design 11(3): 725-744. http://dx.doi.org/10.1080/14680629.2010.9690301

[22] Velasquez, R.; Bahia, H. 2013. Critical factors affecting thermal cracking of asphalt pavements: towards a comprehensive specification, Road Materials and Pavement Design 14(1): 187-200. http://dx.doi.org/10.1080/14680629.2013.774755

[23] Yavuzturk, C.; Ksaibati, K. 2006. Assessment of Thermal Stresses in Asphalt Pavements Due to Environmental Conditions. Laramie. 45 p.

[24] Apeagyei, a K.; Buttlar, W. G.; Reis, H. 2009. Assessment of low-temperature embrittlement of asphalt binders using an acoustic emission approach, Insight - Non-Destructive Testing and Condition Monitoring 51(3): 129-136.

[25] Zafir, Z.; Siddharthan, R; Sebaaly, P.E. 1994. Dynamic pavement-strain histories from moving traffic load, Journal of Transportation Engineering 120(5): 821-843. http://dx.doi.org/10.1061/(ASCE)0733-947X(1994)120:5(821)

[26] Melo, A. S. 1974. Notas sobre Dimensionamento de Pavimentos Rodovia'rios. Porto, Portugal.

[27] I.C.A.O. 1983. Aerodrome Design Manua. Part 3-Pavements. Second Edition. International Civil Aviation Organisation (I.C.A.O.). Monmeal, Canada.

[28] Knapton, J. 2007. Heavy Duty Pavements. The Structural Design of Heavy Duty Pavements for Ports and Other Industries. $4^{\text {th }}$ Edition. Leicester: British Precast Concrete Federation. $89 \mathrm{p}$

[29] Moffatt, J.; Nichol, F. 2009. Port Pavement Design Guide. California. 232 p.

[30] Knapton, J.; Smith, D. R. 1997. Port and Industrial Pavement Design with Concrete Pavers. $2^{\text {nd }}$ Edition. Interlocking Concrete Pavement Institute. $66 \mathrm{p}$

[31] Gesamtverband der Deutschen Versicherungswirtschaft. 2013. Conteiner Handbook. Cargo loss prevention information from German marine insurers. [online]. [cited 20 November 2013] Available from Internet: http://www.containerhandbuch.de.

[32] Dongmo-Engeland, B.; Benedetto, H. Di. 2005. A Contribution to the Modeling of Permanent Deformations of Bituminous Mixes. In BCRA 2005 Conference. Trondheim, 1-10.

[33] Kim, K. W.; Doh, Y. S.; Amrikhanian, S. N. 2004. Feasibility of Deformation Strength for Estimation of Rut Resistance of Asphalt Concrete, Road Materials and Pavement Design 5(3): 303-322. http://dx.doi.org/10.1080/14680629.2004.9689974

[34] Roberts, F.; Kandhal, P., Brown, E. R.; Lee, D.Y.; Kennedy, T. 1996. Hot mix asphalt materials, mixture design, and construction. $2^{\text {nd }}$ Edition. Lanham, Maryland: NAPA Reaserach and Education Foundation.

[35] Salter, K. J.; Shkaarshi, M. T. O. 1990. Effect of Ambient Temperature and Thermal Cycling on the Creep of Bituminous Paving Materials, Transportation Research Record 1228, Transportation Research Board, National Research Council. Washington D.C., 106-111.

[36] Paliukaite, M.; Vaitkus, A. 2011. Analysis of Temperature and Moisture Influence on Asphalt Pavement Strength, in Proc. of The $8^{\text {th }}$ International Conference "Environemental Engineering” May 19-20, 2001, Selected papers 3: 1160-1165.

[37] Miljkovic, M.; Radenberg, M. 2011. Rutting mechanisms and advanced laboratory testing of asphalt mixtures resistance against permanent deformation, Facta Universitatis - Series: Architecture and Civil Engineering 9(3): 407-417. http://dx.doi.org/10.2298/FUACE1 103407M

[38] Kandhal, P. S.; Cooley, L. A. Jr. 2003. NCHRP Report 508: Accelerated Laboratory Rutting Tests: Evaluation of the Asphalt Pavement Analyzer. Transportation Research Board, Washington, D.C.

[39] Vaitkus, A.; Laurinavičius, A.; Oginskas, R.; Motiejūnas, A.; Paliukaite, M.; Barvidienè, O. 2012. The road of experimental pavement structures: experience of five years operation, The Baltic Journal of Road and Bridge Engineering 7(3): 220-227. http://dx.doi.org/10.3846/bjrbe.2012.30

[40] Doré, G.; Zubeck, H. K. 2009. Cold Regions Pavement Engineering. United States of America: American Society of Civil Engineers. 460 p. ISBN 978-0-07-160088-0.

[41] Nicholls J. C.; Carswell I. 2001. The behaviour of asphalt in adverse hot weather conditions. TR 494. TRL Limited, Crowthorne.

[42] Boutin, G.; Lupien, C. 2000. Thermal Cracking of Asphalt Pavement, in Proc. The $2^{\text {nd }}$ Eurasphalt and Eurobitume Congress, Barcelona, 2000, 45-59. 
Appendix A. Pavement structures using for areas affected by static and impact load a)

\begin{tabular}{|c|c|c|c|c|c|}
\hline \multirow{2}{*}{$\begin{array}{c}\text { Type of } \\
\text { pavement }\end{array}$} & \multicolumn{5}{|c|}{ Object of application } \\
\hline & Parking aprons of aircraft & Ports and containers terminals & Logistics terminals & Industrial areas & Parking lots \\
\hline \multirow{7}{*}{ Flexible } & 5-10 Asphalt surface course & 5-10 Asphalt surface course & 3-4 Asphalt surface course & 3-4 Asphalt surface course & $2.5-4$ Asphalt surface course $\left.{ }^{b}\right)$ \\
\hline & 8-9 Aspliall binder course & 8.9 Asphalt binder course & 6-8 Asphalt binder course & 6-8 Asphalt binder course & 4-6 Asphalt binder course \\
\hline & $\begin{array}{l}\text { 25-60 Unbound granular } \\
\text { subbase course }\end{array}$ & $\begin{array}{l}\text { 25-60 Unbound granular } \\
\text { subbasc course }\end{array}$ & $\begin{array}{l}\text { 25-50 Unbound granular } \\
\text { subbase course }\end{array}$ & $\begin{array}{l}\text { 15-50 Unbound granular } \\
\text { subbase course }\end{array}$ & $\begin{array}{l}\text { 15-30 Unbound granular } \\
\text { subbase course }\end{array}$ \\
\hline & & & & & \\
\hline & $\geq 8$ Concretc paving blocks & $\geq 8$ Concrete paving blocks & $\geq 8$ Concrete paving blocks $\left.{ }^{c}\right)$ & $\geq 8$ Concretc paving blocks ${ }^{c}$ & $\geq 8$ Concrete paving blocks ${ }^{c}$ ) \\
\hline & $\begin{array}{l}\text { 12-30 Unbound granular } \\
\text { base course }\end{array}$ & $\begin{array}{l}\text { 12-30 Unhound granular } \\
\text { base course }\end{array}$ & $\begin{array}{l}\text { 25-50 Unbound granular } \\
\text { base course }\end{array}$ & $\begin{array}{l}\text { 25-50 Unbound granular } \\
\text { base course }\end{array}$ & $\begin{array}{l}\text { 15-30 Unbound granular } \\
\text { base course }\end{array}$ \\
\hline & $\begin{array}{l}\text { 15-30 Unbound granular } \\
\text { subbase course }\end{array}$ & $\begin{array}{l}\text { 15-30 Unbound granular } \\
\text { subbase course }\end{array}$ & & & \\
\hline
\end{tabular}




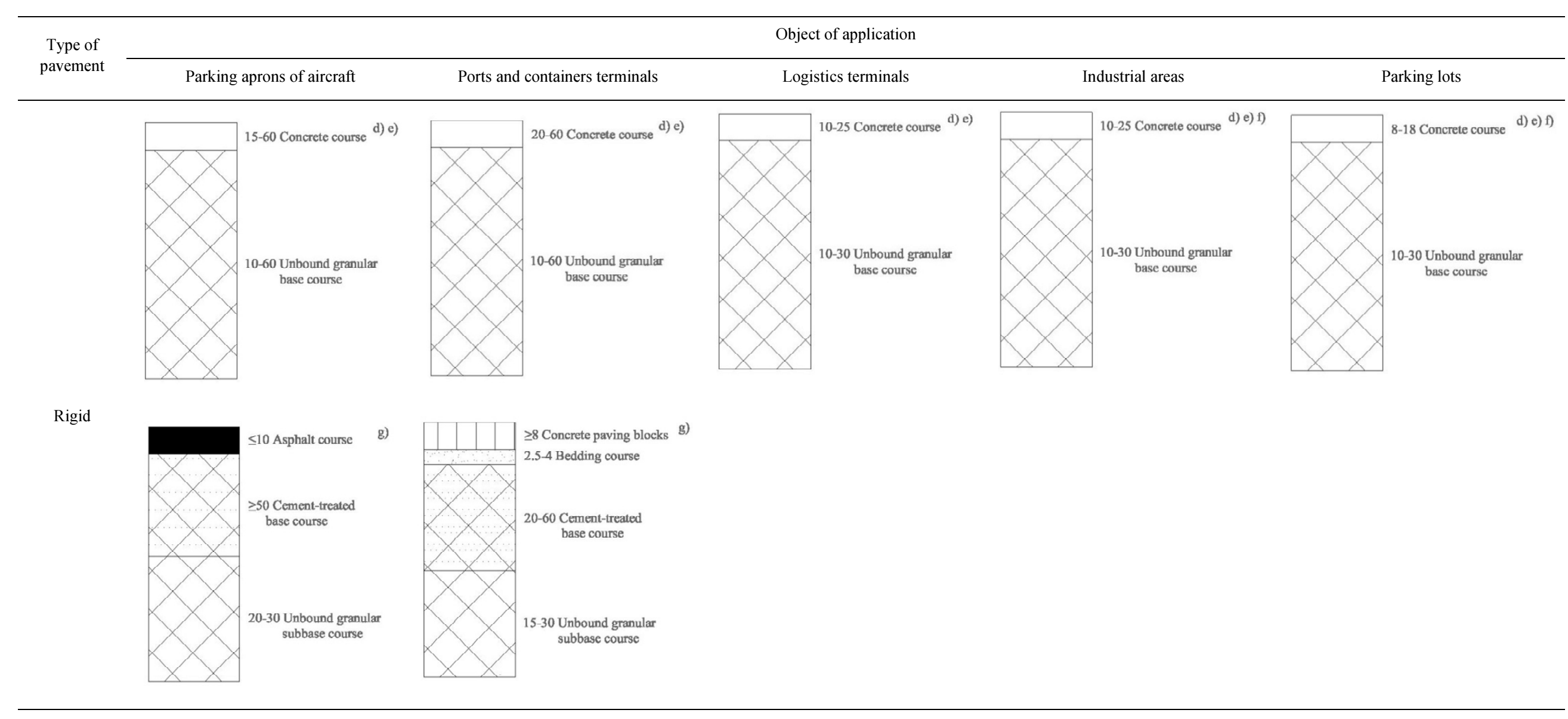




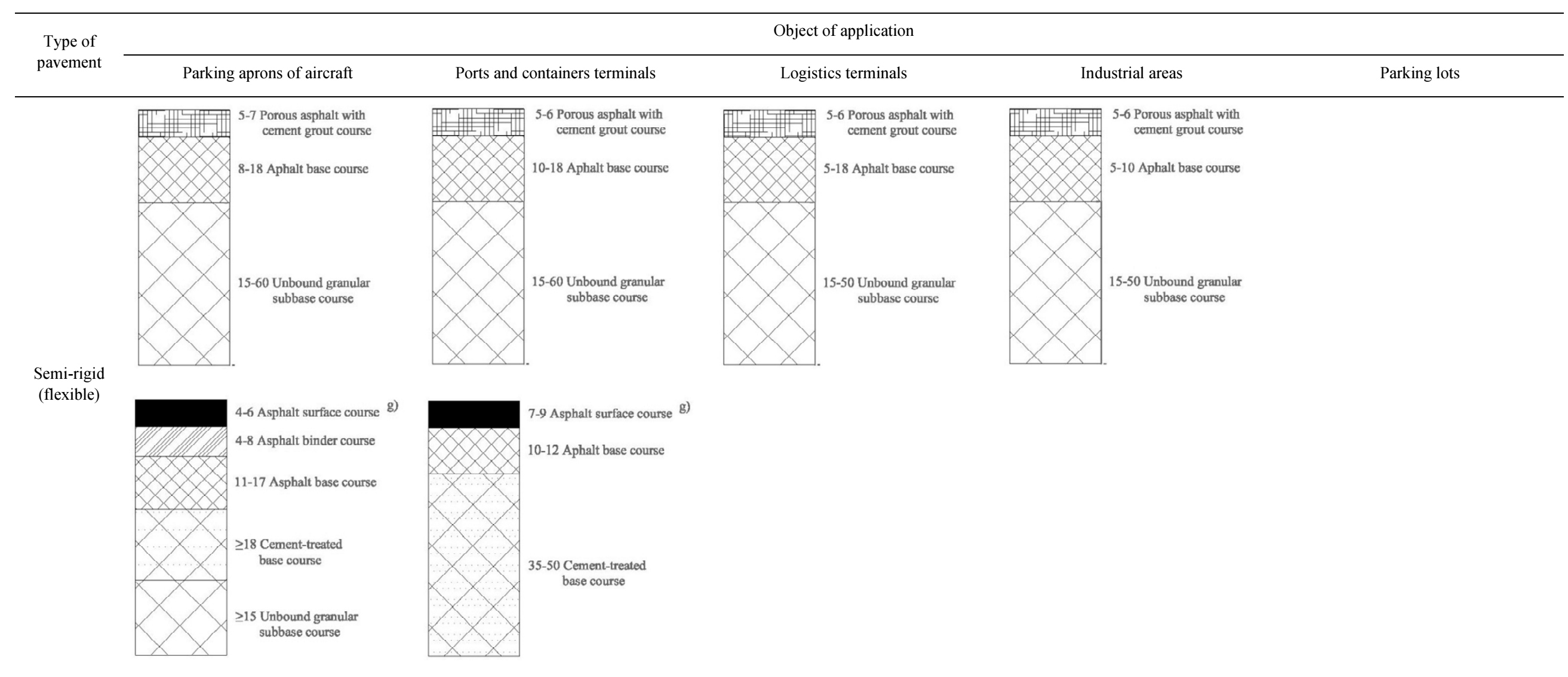

a) it has been found only one solution for areas effected by impact load. It consists of 4-7 $\mathrm{cm}$ porous asphalt with cement grout course, 10-14 $\mathrm{cm}$ asphalt base course and unbound base granular course.

b) this pavement structure using for parking lots can consist without asphalt binder course.

c) the upper part of the base course $(\geq 8 \mathrm{~cm})$ can consist of asphalt-treated material. Then the thickness of bottom part of the unbound granular base course is $15-30 \mathrm{~cm}$

d) the porous asphalt with cement grout course $(3-7 \mathrm{~cm}) \mathrm{can}$ be placed on the concrete pavement.

e) the upper part of the base course can consist of cement-treated material.

${ }^{f}$ the pavement can consist only of concrete course constructing on subgrade (without base course).

g) the same type of pavement can be used for parking aprons of aircraft, ports and containers terminals. 